\title{
chatchenko 0. RESEARCH OF PRACTICAL ASPECTS OF THE MODELING OF THE RISK TOLERANCE MANAGEMENT SYSTEM OF BUSINESS MODELS OF RESTAURANT BUSINESS ENTERPRISE
}

Об'єктом дослідження є процес управління ризикостійкістю бізнес-моделі підприємства ресторанного господарства. Одним з найбільш проблемних місць при реалізації бізнес-моделі підприємства є своєчасне розпізнавання ризику та мінімізація його впливу на діяльність. Ресторанне господарство є найбільш прибутковим та рентабельним у світі. Конкуренція у даній сфері згодом зростає. Ризик виникає там, де існує прибуток і конкуренція, а також є різні варіанти, пов'язані з ймовірністю настання ризику в умовах невизначеності. Ідентифікаиія та врахування факторів ризику є основою для прийняття управлінських рішень щодо своєчасної трансформації діючої бізнес-моделі підприємства відповідно до змін зовнішнвого середовища.

Показано, що прощес управління ризиком підприємства ресторанного господарства пов'язаний із складністю виявлення ключових аспектів ризикостійкості його бізнес-моделі та необхідністю врахування ризиків, які виникають в процесі створення цінності. Це обумовлено особливостями набору ризиків і характеру їх пролву у сфері ресторанного бізнесу. Для підприємства ресторанного господарства характерні специфічні групи ризиків. Дані ризики пов'язані із формуванням та просуванням ціннісних пропозицій, потоками надходження доходів та взаємовідносинами з клієнтами/споживачами.

Визначено етапи моделювання системи управління ризикостійкістю бізнес-моделі підприємства ресторанного господарства. Ці етапи передбачають визначення основних груп ризиків та ключових систем управління цінністю, оцінку їх параметрів та дозволяють визначити комплекс управлінських рішень щодо підвищення рівня ризикостійкості бізнес-моделі підприємства ресторанного господарства.

Для реалізації етапів моделювання системи управління ризикостійкістю бізнес-моделі підприємства ресторанного господарства запропоновано алгоритм, який грунтується на теорії нечітких множин з можливістю оцінки відповідності фактичних параметрів системи иільовим їх значенням.

Завдяки цьому забезпечується можливість оцінки фактичного стану системи управління ризикостійкістю бізнес-моделі підприємства за ключовими бізнес-прочесами. Розроблений комплекс управлінських рімень створює можливість здійснення своєчасної реакиї̈ підприємства ресторанного господарства на різного роду ризики в умовах ресурсних та часових обмежень.

ключові слова: ризикостійкість бізнес-моделі підприємства, комплекс управлінських рішень, моделювання системи управління.

\section{Introduction}

The restaurant business is associated with a large number of risks. Some risks are simple and usually are not taken into account by restaurateurs, however, they can have a direct impact on reputation, financial condition and can cause an immediate failure of restaurant enterprises. In addition, some of the risks are hidden and can lead to the loss of restaurant facilities by the enterprise in the restaurant business. Risk constitutes an objectively inevitable element of making any managerial decision due to the fact that uncertainty is an inevitable characteristic of business conditions [1].

Risk management in the restaurant business is also complicated by the fact that there is a possibility of occurrence and favorable events in the enterprises of this industry, which is also a risk. For example, a large flow of visitors to a cafe is also a risk, since cooks and waiters may not be ready for quick and high-quality customer service, which will lead to negative consequences.

Any activity in conditions of uncertainty is characterized by the types of risks corresponding to this activity. The level of risk depends on many factors, both related and unrelated to the activities of the enterprise. Business leaders constantly need to make management decisions in the face of uncertainty. The importance of solving this issue is enhanced in a turbulent external environment. Since, as practice shows, in a risk situation, very often, in fact, management decisions tend to deviate from previously agreed decisions. Risk always exists objectively, regardless of whether it is taken into account or not. The consequence of the manifestation of risk is a decrease in the efficiency of the enterprise as a whole.

Therefore, modeling the risk tolerance management system of the business model of a restaurant business enterprise is relevant, because it creates an opportunity 
not only to control the risk situation, but also helps to avoid future risks. Its implementation creates the opportunity to prepare for various kinds of risk situations to achieve strategic business goals.

\section{The object of research and its technological audit}

The object of research is the risk tolerance management process of the business model of a restaurant enterprise. Efficient, flexible and risk tolerance business model of an enterprise is one of the key factors of competitive success. High risk tolerance of the business model creates the possibility of «protecting» the restaurant business enterprise from various fluctuations of the external environment.

The process is complicated by the fact that the business model of each enterprise of the restaurant industry is individual, since in the process of its formation a specific set of strategic resources, opportunities and key competencies is used. The risk management process of the business model of a restaurant business enterprise should be considered as a set of risks. Taking into account the industry characteristics of the restaurant business, these risks are associated with the formation and promotion of value propositions, with revenue streams and with relationships.

Consequently, one of the problem areas is the study of the modeling aspects of the risk tolerance management system of a restaurant enterprise, taking into account the key value-creating processes. The problem can be attributed to the insufficiently studied, which, accordingly, expands the range of areas of scientific research in this direction.

\section{The aim and objectives of research}

The aim of research is determination of the stages of modeling the risk tolerance management system of the business model of a restaurant business enterprise.

To achieve this aim, the following objectives are set:

1. To identify groups of risks affecting the state of the risk tolerance management system of the business model of a restaurant business enterprise.

2. To form key value management systems that determine the state of the risk tolerance management system and propose the main stages of its modeling.

3. To develop a set of alternative management efforts to increase the risk tolerance level of the business model of the restaurant business enterprise.

\section{Research of existing solutions of the problem}

The research of theoretical and methodological aspects of risk management is devoted to the work of many scientists. In these works, the theoretical foundations of enterprise risk management are investigated, the results of which proved that, in order to preserve viability, any enterprise should strive not to avoid risk, but to be able to correctly assess its level. And also directly manage it for the purpose of limiting. This requires timely consideration of risk factors in making management decisions and a qualified organization of the risk management process in accordance with the changing conditions of the external and internal environment [1, 2].

The theoretical aspects of risk management are covered in $[3,4]$. In particular, empirical evidence regarding the cost of risk is given in $[5,6]$. Of course, today the cost of risk for any enterprise is quite high, which makes it necessary to level risks.

In [7], it is proved that the creation of a flexible and adaptive risk tolerance management system at an enterprise allows to adequately respond to various kinds of risky situations.

Considerable attention is paid to risks in the implementation of innovative business models of enterprises in various spheres of economic activity. The most convincing practical aspects of risk management in the formation of an innovative business model are given in [8]. The results of these studies have shown that operational, technical and market risks have the most significant impact on innovative business models. At the same time, any innovative model with time requires transformation and adaptation, respectively, of changes in environmental factors, which, in turn, generates new types of risk.

In $[9,10]$, the authors summarize a set of measures to minimize the consequences of risk manifestation in the activities of enterprises. As a rule, the main objective of a risk management program in an enterprise is provision of an enabling environment for its successful operation under risk. At the same time, any risk management program requires appropriate adjustments and taking into account industry specifics.

The author of [11] describes risk tolerance as resistance to the effects of risks. As a rule, the low sensitivity of business activities to the effects of risks is achieved with the help of adequate and effective business solutions.

In $[12,13]$, the authors consider the issues of risk assessment at certain stages of the formation of the business model of the enterprise. The author of [13] in determining the level of risk protection of an enterprise highlights the problem of integrated assessment of financial and economic performance indicators. As a rule, for a comprehensive risk assessment in the management system of the business model of the enterprise, it is necessary to focus on environmental factors.

There are a significant number of risk diagnosis techniques. Methodical aspects of diagnosing risks are described in [14]. The approach allows to assess the technological, organizational and commercial risks on an individual basis. However, the proposed approach does not take into account the information, investment, property and other types of risks characteristic of enterprises of restaurant industry.

So, the main studies on the theoretical and methodological aspects of risk management in enterprises are considered and the main key problems that arise in the risk management process are identified. In addition, the main types of risks of innovative business models of enterprises are considered. However, a significant range of applied issues related to modeling the risk tolerance management system of the business model of a restaurant business enterprise, taking into account industry specifics, requires practical solutions. This issue is particularly acute in the conditions of growing volatility of the external environment, various kinds of uncertainties inherent in demand, supply, actions of stakeholders, the quality of the restaurant product, the availability of labor, the adoption of a product by the market, and technical progress. In addition, the formation of an optimal business model for a restaurant business enterprise is impossible without taking into account a risk factor. The lack of universal methods for risk assessment 
and means of minimizing it makes promising the modeling of the risk tolerance management system of the business model of a restaurant business enterprise.

\section{Methods of research}

General scientific and special research methods are applied:

- analysis and synthesis - for techno-

logical audit of the object of research; - structuring - to identify the main risk groups and the elements of the risk tolerance system of the restaurant business enterprise model;

- theory of fuzzy sets - for modeling the risk tolerance management system of the business model of a restaurant business enterprise;

- matrix analysis - to build relationships between the state of the risk tolerance management system of the business model of the restaurant business enterprise and its components;

- expert assessments - to assess the elements of risk tolerance management system of the business model of a restaurant business enterprise;

- one-dimensional and multidimensional statistical analysis of data - to summarize the results of modeling the risk tolerance management system of the business model of a restaurant enterprise.

\section{Research results}

One of the ways to solve fuzzy problem situations is the theory of fuzzy sets and fuzzy measures, the founder of which is the famous American scientist Lotfi Zadeh [15]. The theory of fuzzy sets allows to take into account, besides quantitative indicators, also qualitative aspects that do not have an exact numerical interpretation. General risk characteristics allow this category to be respected as a fuzzy characteristic. Therefore, to assess the risk tolerance management system of the business model of a restaurant business enterprise, the toolkit of the theory of fuzzy sets can be applied.

The modeling of the risk tolerance management system of the business model of a restaurant business enterprise is based on the theory of fuzzy modeling. The details of the modeling stages are shown in Fig. 1.

At the initial stage of modeling the risk tolerance management system of the business model of a restaurant enterprise, it is necessary to identify the main descriptors that determine the state of the risk tolerance management system of the business model of a restaurant enterprise. Let the object $L$ (the risk tolerance management system of the business model of a restaurant enterprise) have $f$ essential parameters, $h_{i}$, where $i \in(1, f)$, describes the state of the $i$-th system parameter, the vector $B=\left\{b_{i}\right\}$ - the state of the entire management object. The initial state of the risk tolerance management system of the business model of the restaurant business enterprise will be characterized by the $B_{0}$ vector. The relation $Q_{B \rightarrow B}$ determines the mutual influence of the elements of the risk tolerance management system of a separate business model of a restaurant business enterprise. It should be noted that these relations essentially depend on the initial state of the risk tolerance management system of the business model of the restaurant business enterprise. Denote the relation due to $B_{0}$ as follows: $Q_{B \rightarrow B}^{B 0}$.
Stage 1. Identification of descriptors that determine the state of the risk tolerance management system of the business model of the restaurant business enterprise,

Stage 2. Establishment of a descriptor of targets and the relationship between the

Stage 3. Evaluation of the relationship between the state of risk tolerance $\checkmark$ $\downarrow$ management system of a business model and management performance

Stage 4. Determination of reference (desired) values based on indicators of business model management and object parameters

Stage 5. Comparison of the actual parameters of the business model management Stage 6. Assessment of the possibility of applying managerial impact on ity of applying managerial impact on
s of the business model of a restaurant optimizing the ste

Stage 7. Development of a complex of managerial efforts for a risk tolerance management system for a business model of a restaurant business enterprise

Fig. 1. The structure of the process of modeling the risk tolerance management system of the business model of a restaurant business enterprise (developed on the basis of [15, 16])
The vector $N=\left\{n_{i}\right\}$ characterizes the state of the risk tolerance management system of a separate business model of the restaurant business enterprise (input elements that influence), and the vector $K=\left\{k_{i}\right\}$ indicates the state of the components of the business model (output elements of the object to be affected). Wherein, $N \subset B, K \subset B,(N \cup K) \subseteq B$.

From the set of internal relations, it is important $Q_{N \rightarrow K}$, that is, relations characterizing the influence of the components of the risk tolerance management system on the components of the business model of the restaurant business enterprise, where $Q_{N \rightarrow K}, Q_{N \rightarrow K} \subset Q_{B \rightarrow B}^{B 0}$.

It is advisable to assess the state of the risk tolerance management system of the business model of a restaurant business based on the business model components identified in [17]: the value creation system $\left(k_{1}\right)$, the offer generation system $\left(k_{2}\right)$, and the customer value creation system $\left(k_{3}\right)$. These components of the business model together form the vector $K=\left(\begin{array}{lll}k_{1} & k_{2} & k_{3}\end{array}\right)$. Considering this, the risk tolerance management system of the business model of the restaurant business enterprise should cover the range of three risk groups, namely:

1) related to the formation and promotion of value propositions $\left(n_{1}\right)$;

2 ) income streams associated with income $\left(n_{2}\right)$;

3) related to customer/consumer relationships $\left(n_{3}\right)$. These risk groups together form the vector $N=\left(\begin{array}{lll}n_{1} & n_{2} & n_{3}\end{array}\right)$.

Identification of a certain range of risks is carried out on the basis of fuzzy logic methods. For the ranking of risk groups and indicators in each group, the Saaty scale [16] is used. 
The assessment of the degree of risk by the constituent elements of the $i$-th component of the business model $K_{i}$ and the elements of the risk tolerance in the system $N_{i}$ is carried out on the basis of expert assessment method [18]. For evaluation, a 5-point scale is used, according to which -1 point characterizes low risk influence, respectively, 5 points - high impact. The obtained results are reduced to the interval $(0 ; 1)$.

The determination of the influence of the vector $N$ on the vector $K$ is carried out on the basis of fuzzy estimates from the interval $(0,1)$, while a fuzzy rating of 0.5 describes neutral ratios. The enhancement of a negative or positive relationship characterizes approximations to the boundaries of the evaluation interval ( 0 or 1$)$. It should be noted that it is important to compare quality shades for fuzzy assessments determining the state and attitude: a rating of 0.5 characterizes a neutral level of communication and an average level of object exposure. Strengthening the relationship between elements and the level of influence between them characterizes the limit of the estimated interval of fuzzy estimates from 0.5 to 1 .

So, the relationship between the state of the risk tolerance management system of the business model of the restaurant business enterprise and its components is described by the matrix:

$$
Q_{N \rightarrow K}^{B 0}=\left(\begin{array}{l}
b_{11} b_{12} b_{13} \\
b_{21} b_{22} b_{23} \\
b_{31} b_{32} b_{33}
\end{array}\right) .
$$

To recognize the descriptor of targets and the relationship between the parameters of the object and the goals of the restaurant business enterprise, the following assumptions should be made:

- vector $G=\left\{g_{j}\right\}$, where $j \in(1, p)$ describes the state of the resulting parameters of the risk tolerance management system;

- $G_{0}$ - the current state of these system parameters,

which characterizes risk management performance indicators.

Let's denote the state of the parameters characterizing the effectiveness of risk management, the vector $W$, in this case $W \subseteq G$.

To assess the state of effectiveness of risk tolerance management on the business model of a restaurant enterprise, it is advisable to take into account the values of such indicators as:

- profitability level $\left(g_{1}\right)$;

- degree of achievement of business goals $\left(g_{2}\right)$;

- customer loyalty level $\left(g_{3}\right)$.

Defined performance indicators form the vector $G=$ $=\left(\begin{array}{lll}g_{1} & g_{2} & g_{3}\end{array}\right)$.

In turn, the actual values of business model risk tolerance management performance indicators determine the state of management for each component of the business model, which is determined by the ratio $Q_{K \rightarrow G}^{W 0}$. This assessment is carried out similarly to the previous relation based on fuzzy estimates:

$$
Q_{K \rightarrow G}^{W 0}=\left(\begin{array}{ccc}
w_{11} & w_{12} & w_{13} \\
w_{21} & w_{22} & w_{23} \\
w_{31} & w_{32} & w_{33}
\end{array}\right) .
$$

The fuzzy matrix was built, which allows determining the list of parameters affecting the achievement of full compliance of the risk tolerance parameters of the business model with the needs of the restaurant business enterprise as a whole.

Based on the need for an integrated approach to the formation of the business model of the enterprise, it has been established that the target installations of the restaurant business enterprise depend on:

- the state of management of the risk tolerance of the business model;

- the relationship between the parameters of the object and performance indicators.

This relationship can be represented as the following model:

$$
G=F\left(N, Q_{N \rightarrow K}^{B 0}, Q_{K \rightarrow G}^{W 0}\right) .
$$

The value of the parameter $G$ depends on the degree of complexity and the nature of the interactions between the arguments: $N, Q_{N \rightarrow K}^{B 0}, Q_{K \rightarrow G}^{W 0}$. Let's note that the complexity degree depends on the elemental completeness of the formal description, used mathematical apparatus, the quantitative or qualitative definiteness of the problem parameters.

In order to ensure the consistency of the parameters of the state of the risk tolerance management system, it is advisable to carry out the operation of maximin composition. This will help to preserve the quality load resulting from fuzzy evaluations.

The essence of the operation maximin composition is as follows:

- for the formation of the element $t_{i j}$ of the resulting matrix, pairwise minima are determined;

- pairwise minima are determined among the corresponding elements of the $i$-th row of the first and $j$-th column of the second matrix;

- from the found minimums the greatest is chosen.

Such an approach is justified, since under the condition of a low level of influence of the $i$-th parameter of risk tolerance on the resulting indicator of management efficiency of the business model of the enterprise, there is no possibility to increase it.

To find the matrix $Q_{N \rightarrow G}$, manifesting implicit connections between the state of the risk tolerance management system and the management efficiency indicators, multiplications of the matrices $Q_{N \rightarrow K}^{B 0}$ and $Q_{K \rightarrow G}^{W 0}$ are performed.

So, the matrix $Q_{N \rightarrow G}$ has the following form:

$$
\begin{aligned}
& Q_{N \rightarrow G}=Q_{N \rightarrow K}^{B 0} \cdot Q_{K \rightarrow G}^{W 0}=\left(\begin{array}{lll}
b_{11} & b_{12} & b_{13} \\
b_{21} & b_{22} & b_{23} \\
b_{31} & b_{32} & b_{33}
\end{array}\right) \cdot\left(\begin{array}{ccc}
w_{11} & w_{12} & w_{31} \\
\omega_{21} & w_{22} & w_{23} \\
\omega_{31} & w_{32} & w_{33}
\end{array}\right)= \\
& =\left(\begin{array}{lll}
b_{11} \omega_{11} & b_{12} \varpi_{12} & b_{13} \varpi_{13} \\
b_{21} w_{21} & b_{22} \varpi_{22} & b_{23} \varpi_{23} \\
b_{31} \omega_{31} & b_{32} \varpi_{32} & b_{33} \varpi_{33}
\end{array}\right) .
\end{aligned}
$$

On the basis of this mathematical iteration, the relationship between the risk tolerance management system of the business model of the restaurant business enterprise and the management efficiency indicators for each component is determined. 
The desired state of the parameters, determines the achievement of the restaurant business enterprise target level of performance indicators, given by the vector $S_{t}$ :

$$
S_{t}=(1 ; 1 ; 1) \text {. }
$$

Achievement of certain reference (desired) values of business model management performance indicators requires a certain state of the risk tolerance management system. This necessitates the determination of reference (desired) values of two parameters: the state of the components of the business model and the state of the risk tolerance management system of the business model. This assessment should be carried out using the maximin composition between the vector of reference (desired) values of business model management performance indicators and the corresponding fuzzy matrices $Q_{K \rightarrow G}$ and $Q_{N \rightarrow G}$. The vectors $N_{t}$ and $K_{t}$ are defined as follows:

$$
\begin{aligned}
& N_{t}=Q_{N \rightarrow G} \cdot S_{t}= \\
& =\left(\begin{array}{lll}
b_{11} \varpi_{11} & b_{12} \varpi_{12} & b_{13} \varpi_{13} \\
b_{21} \varpi_{21} & b_{22} \varpi_{22} & b_{23} \varpi_{23} \\
b_{31} \varpi_{31} & b_{32} \varpi_{32} & b_{33} \varpi_{33}
\end{array}\right) \cdot\left(\begin{array}{lll}
1 & 1 & 1
\end{array}\right)=\left(\begin{array}{lll}
1 & 1 & 1
\end{array}\right) . \\
& K_{t}=Q_{K \rightarrow G} \cdot S_{t}= \\
& =\left(\begin{array}{lll}
k_{11} \varpi_{11} & k_{12} \varpi_{12} & k_{13} \varpi_{13} \\
k_{21} \omega_{21} & k_{22} \omega_{22} & k_{23} \varpi_{23} \\
k_{31} \varpi_{31} & k_{32} \varpi_{32} & k_{33} \varpi_{33}
\end{array}\right) \cdot\left(\begin{array}{lll}
1 & 1 & 1
\end{array}\right)=\left(\begin{array}{lll}
1 & 1 & 1
\end{array}\right) .
\end{aligned}
$$

At stage 5, the calculation of the maximin composition $\left(G_{0(N)}\right)$ is carried out. This composition is calculated between the following elements:

- vector of the existing position of the risk tolerance management system $\left(N_{0}\right)$;

- fuzzy matrix of the influence of each $i$-th subsystem on the business model management performance indicators $\left(Q_{N \rightarrow G}\right)$.

The calculation of the maximin composition is carried out according to the following model:

$$
G_{0(N)}=N_{0} \cdot Q_{N \rightarrow G} .
$$

The vector $T_{0}$ is determined by the actual state of the risk tolerance management system identified at the previous stage of the study. After that, the obtained values of the efficiency indicators are compared with the reference values in order to determine the gaps between them $\Delta G=\left(G_{0}-G_{t}\right)$ caused by the existing gaps $\Delta N=\left(N_{0}-N_{t}\right)$.

Depending on the absolute value of the existing gaps $\left(\Delta N_{i}\right)$, the vector of management efforts is determined. Implementation of the developed management decisions will contribute to the improvement of the state of a separate risk tolerance management subsystem of the business model of the restaurant business enterprise.

Considering that the state of the risk tolerance management system of the business model of an enterprise depends on the degree of development of the constituent elements of the $i$-th component of the business model $\left(K_{i}\right)$, the issue of calculating the maximin composition $\left(G_{0(K)}\right)$ is actualized. This composition describes the relationship between the state vector of the system of components of the business model $\left(N_{0}\right)$ and the fuzzy matrix of the influence of each $i$-th subsystem on the performance indicators of the business model management $\left(Q_{N \rightarrow G}\right)$. The maximin composition is calculated according to the model:

$$
G_{0(K)}=K_{0} \cdot Q_{K \rightarrow G} .
$$

The values of the efficiency indicators obtained as a result of the calculations are compared with the reference ones in order to determine the gaps between them $\Delta G=\left(G_{0}-G_{t}\right)$. Let's note that the actual values of $\Delta G$, due to existing gaps within the components of the business model $\Delta K=\left(K_{0}-K_{t}\right)$ :

- value systems $\left(k_{1}\right)$;

- offer generation systems $\left(k_{2}\right)$;

- customer value creation systems $\left(k_{3}\right)$.

The calculation results obtained at this stage create the opportunity to make the right choice of optimal management efforts for each component of the business model of the restaurant business enterprise. Let's note that the informational basis for this choice is the absolute value of the discontinuities $\left(\Delta K_{i}\right)$.

To assess the direction of management impact in relation to a specific component of the enterprise's business model, it is necessary to establish the appropriate communication composition $\left(K_{f}\right)$. This composition is based on a combination of the state vector of the risk tolerance management system of the business model $\left(N_{0}\right)$ and the fuzzy matrix of the influence of risk tolerance subsystems on the components of the business model $\left(Q_{N \rightarrow K}\right)$. The calculation described maximin composition is carried out according to the model:

$$
K_{f}=N_{0} \cdot Q_{N \rightarrow K} .
$$

The obtained values allow to characterize the target (desired) state of the components of the risk tolerance management system of the business model of the restaurant business enterprise.

According to the results of calculations carried out at this stage, the possibilities of applying managerial influence to a separate component of the business model are determined. The width of these capabilities is determined depending on the size of the deviation of the real state of the components of the business model from the possible $\left(\Delta K_{f}\right)$. The greater the value of the $\Delta K_{f}$ indicator, the lower the correspondingly the possibility of a restaurant business enterprise regarding the improvement of the state of the business model component.

This is due to the fact that the volume of management efforts of the restaurant business enterprise is inversely related to $\Delta K_{f}$. As in the structure of the risk tolerance management system of the business model of an enterprise there may be elements that are not amenable to managerial influence, but depend on other factors.

To determine the relative importance of management efforts, an integral indicator of the risk tolerance of the business model $\left(I_{N \times K}\right)$ is proposed:

$$
I_{N \times K}=\sqrt{\Delta N_{i} \cdot \Delta K_{j}} .
$$

At this stage, the intervals are justified by the value of $I_{n \times k}$ based on a generalized estimate of the average values. For this, the minimum $(0,0)$ and maximum (1.0) 
values are determined. The range of changes in the values of the $I_{N \times K}$ index is calculated by the Fishburn criterion [17]:

$$
I_{N \times K}=\frac{I_{n \times k} \max -I_{n \times k} \min }{1+3.322 \cdot L g k},
$$

where $I_{n \times k} \max , I_{n \times k} \min$ - the maximum and minimum value of the indicator for making decisions on risk tolerance management of the business model of the enterprise; $l$ - the number of observations.

The level of management efforts regarding the improvement of the risk tolerance management system of the business model of a restaurant business enterprise depends on the actual value of the $I_{N \times K}$ indicator. In order to increase the risk tolerance level of the business model of the restaurant business enterprise, alternative levels of management efforts have been established and a set of relevant management decisions has been proposed (Table 1).

Table 1

Complex management decisions to improve the risk tolerance level of the business model of a restaurant business enterprise

\begin{tabular}{|c|c|}
\hline $\begin{array}{l}\text { Level of manage- } \\
\text { ment decisions }\end{array}$ & Recommended management solutions \\
\hline $\begin{array}{l}\text { Optimization } \\
\text { (minimization) } \\
0.0<I_{N \times K}<0.3\end{array}$ & $\begin{array}{l}\text { 1) conducting partial, non-fundamental changes in the } \\
\text { business model; } \\
\text { 2) introduction of minor adjustments in the activities of } \\
\text { the enterprise restaurant; } \\
\text { 3) adaptation of the business model to various kinds of } \\
\text { external and internal environment; } \\
\text { 4) synchronous management of components and busi- } \\
\text { ness model development factors }\end{array}$ \\
\hline $\begin{array}{l}\text { Valid } \\
0.31<I_{N \times K}<0.60\end{array}$ & $\begin{array}{l}\text { 1) update the current business model of the restaurant } \\
\text { business; } \\
\text { 2) transformation of the components of the business } \\
\text { model of the restaurant enterprise; } \\
\text { 3) realization of the possibilities of minimizing the } \\
\text { gap between the current and desired states of the risk } \\
\text { tolerance management system of the business model }\end{array}$ \\
\hline $\begin{array}{l}\text { Critical } \\
I_{N \times K}>0.61\end{array}$ & $\begin{array}{l}\text { 1) changing the concept of the restaurant business; } \\
\text { 2) reengineering of business processes of the existing } \\
\text { business model for value systems, the formation of } \\
\text { proposals and the creation of customer value }\end{array}$ \\
\hline
\end{tabular}

According to the results of practical testing of the proposed approach for assessing the risk tolerance management system, LLC InterFood-Kharkiv (Ukraine) has formed the $Q_{N \rightarrow G}$ matrix:

$$
\begin{aligned}
& Q_{N \rightarrow G}=Q_{N \rightarrow K}^{B 0} \cdot Q_{K \rightarrow G}^{W 0}= \\
& =\left(\begin{array}{lll}
1.0 & 0.6 & 0.8 \\
0.5 & 0.8 & 0.6 \\
0.5 & 1.0 & 1.0
\end{array}\right) \cdot\left(\begin{array}{lll}
1.0 & 0.8 & 0.6 \\
1.0 & 1.0 & 0.8 \\
0.6 & 0.8 & 1.0
\end{array}\right)=\left(\begin{array}{lll}
1.0 & 0.9 & 1.0 \\
0.8 & 1.0 & 0.9 \\
1.0 & 0.9 & 1.0
\end{array}\right) .
\end{aligned}
$$

Vectors $N_{t}$ and $K_{t}$ are calculated:

$$
\begin{aligned}
N_{t}=Q_{N \rightarrow G} \cdot S_{t} & =\left(\begin{array}{lll}
1.0 & 0.9 & 1.0 \\
0.8 & 1.0 & 0.9 \\
1.0 & 0.9 & 1.0
\end{array}\right) \cdot\left(\begin{array}{lll}
1 & 1 & 1
\end{array}\right)=\left(\begin{array}{lll}
1 & 1 & 1
\end{array}\right) . \\
K_{t} & =Q_{K \rightarrow G} \cdot S_{t}=\left(\begin{array}{lll}
1.0 & 0.8 & 0.6 \\
1.0 & 1.0 & 0.8 \\
0.6 & 0.8 & 0.1
\end{array}\right) \cdot\left(\begin{array}{lll}
1 & 1 & 1
\end{array}\right)=\left(\begin{array}{lll}
1 & 1 & 1
\end{array}\right) .
\end{aligned}
$$

According to the Table 2, the risk tolerance of the business model of LLC InterFood-Kharkiv is low, the level

\begin{tabular}{|c|c|c|}
\hline $\begin{array}{l}\text { Parameters of } \\
\text { the risk tole- } \\
\text { rance system } \\
\text { of the business } \\
\text { model }\end{array}$ & Рагаmeter rating indicators & $\begin{array}{l}\operatorname{Gap} \\
\text { value }(\Delta), \\
\text { coefficient }\end{array}$ \\
\hline \multirow{3}{*}{$\begin{array}{l}\text { Business } \\
\text { model risks }\end{array}$} & $\begin{array}{l}\text { Associated with the formation and promotion } \\
\text { of value propositions }\left(n_{1}\right)\end{array}$ & -0.43 \\
\hline & Related income streams $\left(n_{2}\right)$ & -0.37 \\
\hline & Customer/consumer relations $\left(n_{3}\right)$ & -0.50 \\
\hline \multirow{3}{*}{$\begin{array}{l}\text { Value } \\
\text { components } \\
\text { of the business } \\
\text { model }\end{array}$} & Value creation system $\left(\Delta k_{1}\right)$ & -0.32 \\
\hline & Offer generation system $\left(k_{2}\right)$ & -0.31 \\
\hline & Value сгеation system $\left(k_{3}\right)$ & -0.30 \\
\hline \multicolumn{2}{|c|}{ Integral indicator of risk tolerance of the business model $\left(I_{N \times K}\right)$} & 0.63 \\
\hline \multicolumn{2}{|c|}{$\begin{array}{l}\text { The level of management decisions to improve the risk tolerance } \\
\text { of the business model }\end{array}$} & Critical \\
\hline
\end{tabular}
of necessary management efforts is critical.

Table 2

The calculation of the integral risk tolerance indicator of the business model LLC «InterFood-Kharkiv» (Ukraine)

The implementation of the complex recommended in Table 1, management efforts will allow LLC InterfudKharkiv to increase the risk tolerance level of its business model.

\section{SWOT analysis of research results}

Strengths. The strengths lie in the fact that the proposed approach to modeling the risk tolerance management system of the business model of a restaurant business enterprise allows, based on the theory of fuzzy sets, to take into account the mutual influence of three specific risk groups. These risks are associated with the formation and promotion of value propositions related to revenue streams associated with customer/consumer relationships. In addition, the advantage of the approach is the possibility of determining a set of management decisions to ensure a timely response of the restaurant business enterprise to various risks in the context of resource and time constraints.

Weaknesses. The weak side of the proposed approach is that the reliability and reliability of the parameters of the risk tolerance management system of the business model of an enterprise depend on the competence of the specialists involved in this assessment. So experts must have risk management experience. In addition, when determining the optimal number of experts, one should take into account the moment of personal interest, which can be a significant obstacle to obtaining reliable assessment results.

Opportunities. It should be noted that in the future, the risk management process can be supplemented with assessments of experts' competence, consistency of their opinions and reliability of expert assessment methods. To do this, existing software systems can be improved, which are equipped with procedures for creating and processing information, graphic visualization tools, additional system and service tools for working with expert evaluations and the results of their analysis.

Threats. The threats to risk tolerance management of the business model of a restaurant business include latent 
risks that have an indefinite manifestation and carry the potential danger and complexity of consequences. Hidden risks can significantly affect the effectiveness of the implementation of the business model of a restaurant enterprise.

\section{Conclusions}

1. Three groups of risks affecting the state of risk tolerance management of the business model of the restaurant business enterprise are identified: associated with the formation and promotion of value propositions, with revenue streams of income and with customer relationships. They provide for taking into account a wide range of risks of the main structure-forming processes, taking into account the sectoral specifics of restaurant enterprises.

2. The key value management systems in the management of the business model of the restaurant business are formed: creating value, creating supply and creating customer value. They act as a tool for the overall quality management system at restaurant enterprises and create the possibility of taking risks into account for all the main business processes.

The main stages of modeling the restaurant enterprise system are proposed. They provide for the determination of the relationship between the elements of the risk tolerance management system of the business model of a restaurant business enterprise and the management efficiency indicators for each component. As well as the definition and comparison of the parameters of the system of risk tolerance of the business model with reference values.

3. A set of alternative management solutions has been developed, the implementation of which will enable to increase the risk tolerance level of the business model of the restaurant business enterprise.

The practical significance of the research results is the substantiation of the main stages of modeling the risk tolerance management system of the business model of a restaurant business enterprise and the definition of a set of alternative management decisions.

\section{References}

1. Turko M. O. Teoretychni osnovy upravlinnia ryzykamy pidpryiemstva // Ekonomika pidpryiemstva ta upravlinnia vyrobnytstvom. 2007. Issue 5. P. 85-89.

2. Tarasova K. I. Kachestvennyy analiz riskov deyatel'nosti predpriyativa // Oraldy gylym zharshysy (Ural'skiy nauchnyy vestnik). Ekonomicheskie nauki. 2013. Issue 28 (76). P. 72-80.

3. Purdy G. ISO 31000:2009-Setting a New Standard for Risk Management // Risk Analysis. 2010. Vol. 30, Issue 6. P. 881-886. doi: http://doi.org/10.1111/j.1539-6924.2010.01442.x
4. Kravchenko V. Rozrobka suchasnoho standartu z upravlinnia ryzykamy - vazhlyvyi chynnyk pidvyshchennia efektyvnosti pidpryiemnytskoi diialnosti v Ukraini // Teoretychni ta prykladni pytannia ekonomiky. 2008. Issue 17. P. 159-166.

5. Hrosul V. A., Balamut H. S. Otsinka ryzykostiikosti v system adaptatsiinoho upravlinnia rozvytkom torhovelnoho pidpryiemstva // Molodyi vchenyi. 2016. Issue 12 (39). P. 727-729.

6. Hoyt R. E., Liebenberg A. P. The Value of Enterprise Risk Management // Journal of Risk and Insurance. 2011. Vol. 78, Issue 4. P. 795-822. doi: http://doi.org/10.1111/j.15396975.2011.01413.x

7. Kopytina M. V. Adaptive structure of project risks management system // Eastern-European Journal of Enterprise Technologies. 2013. Vol. 1, Issue 3 (61). P. 15-19. URL: http://journals. uran.ua/eejet/article/view/9135

8. Taran Y., Boer H., Lindberg P. Incorporating Enterprise Risk Management in the Business Model Innovation Process // Journal of Business Models. 2014. Vol. 1, Issue 1. P. 38-60.

9. Chesbrough H. Business Model Innovation: Opportunities and Barriers // Long Range Planning. 2010. Vol. 43, Issue 2-3. P. 354-363. doi: http://doi.org/10.1016/j.lrp.2009.07.010

10. Rishchuk L. I., Kushlyk O. Yu. Pidkhid shchodo rozrobky prohramy upravlinnia ryzykamy na pidpryiemstvi // Problemy i perspektyvy rozvytku pidpryiemnytstva. 2015. Vol. 2, Issue 1 (8). P. $77-82$

11. Zubova L. V. Opredelenie riskoustoychivosti predprinimatel'skikh resheniy // Biznes v zakone. Ekonomiko-yuridicheskiy zhurnal. 2015. Issue 5. P. 215-218.

12. Fielt E. Conceptualising Business Models: Definitions // Frameworks and Classifications. 2013. Issue 1 (1). P. 85-105.

13. Artyshchuk I. V. Upravlinnia ryzykozakhyshchenistiu torhovelnoho pidpryiemstva // Zbirnyk naukovykh prats Natsionalnoho lisotekhnichnoho universytetu Ukrainy. 2011. Issue 21.5 . P. $153-159$

14. Keizer J. A., Halman J. I. M. Diagnosing Risk in Radical Innovation Projects // Research-Technology Management. 2007. Vol. 50, Issue 5. P. 30-36. doi: http://doi.org/10.1080/ 08956308.2007.11657459

15. Zadeh L. A. Fuzzy sets // Information and Control. 1965. Vol. 8, Issue 3. P. 338-353. doi: http://doi.org/10.1016/s00199958(65) $90241-x$

16. Saaty T. L. Decision making - the Analytic Hierarchy and Network Processes (AHP/ANP) // Journal of Systems Science and Systems Engineering. 2004. Vol. 13, Issue 1. P. 1-35. doi: http://doi.org/10.1007/s11518-006-0151-5

17. Hrosul V. A., Ivanova T. P. Praktychni aspekty upravlinnia yakistiu pry formuvanni biznes-modeli pidpryiemstva restorannoho hospodarstva // Visnyk NTU «KhPI». Seriia: Mekhanikotekhnolohichni systemy ta kompleksy. 2016. Issue 7 (1179). P. $132-137$.

18. Riid A., Rüstern E. Transparent Fuzzy Systems in Modelling and Control // Interpretability Issues in Fuzzy Modeling. 2003. Vol. 128. P. 452-476. doi: http://doi.org/10.1007/9783-540-37057-4_19

Chatchenko Olga, PhD, Associate Professor, Department of Ma nagement Organizations, Kharkiv State University of Food Technology and Trade, Ukraine, e-mail: chatchenko.o@gmail.com, ORCID: http://orcid.org/0000-0002-4956-7708 